DOI 10.32370/IA_2019_01_8

\title{
Pedagogical Conditions for Forming Future Music Teachers' Readiness to Artistic and Interpretive Activities
}

\author{
Lin Yang \\ ORCID https: orcid.org/ 0000-0002-3129-4035 \\ Postgraduate student (China) \\ Dragomanov National Pedagogical University (Ukraine, Kyiv)
}

\begin{abstract}
The article presents the pedagogical conditions for forming the readiness in future music teachers for their artistic and interpretive activities, namely: the development of biophysical and orphoetic basics of vocal language by students; attentive attitude to the verbal text of a vocal piece, its artistic-figurative content; understanding by students the vocal-performing stylistics of a musical work. According to the first condition, this process should be based on a wide range of knowledge about the nature and mechanisms of sound formation, the laws of forming the singer's voice and management process, understanding the essence of complex phonation phenomena occurring in the human body, ensuring the achievement of the final result - creating artistically convincing interpretation of vocal work. Compliance with the second condition is due to the attentive attitude to the verbal text of the vocal work, its artistic-figurative content. The fulfillment of the third condition involves familiarizing students with the evolution of musical styles in accordance with the history of musical art development, expressive means of musical language, its intonational composition and compositional construction. The implementation of these conditions should be carried out both during the training sessions and in the period of pedagogical practice, in preparation for concert performances, where the process of artistic and interpretive activities is directly underway.

Key words: students, readiness, vocal work, interpretation, artistic and interpretive activities, orphoeography, stylistics.
\end{abstract}

Актуальність дослідження. Однією 3 найважливіших проблем вищої освіти України і Китаю є невідповідність між вимогами ринку праці й запитами сучасної особистості і суспільства. У державних документах обох країн визначені кроки щодо забезпеченні якості підготовки дипломованих фахівців: модернізація структури, змісту та організації освіти на засадах компетентісного підходу; активізація, наукової та інноваційної діяльності, підвищення якості отриманих знань. Виходячи $з$ цього, перед мистецькими вищими навчальними закладами постало першочергове завдання підвищення ефективності підготовки майбутніх учителів музики. Частково означена проблема знайшла своє відображення в працях українських (Л. Василенко, А. Козир, Л. Куненко, Н. Мозгальова, О.Щолокова та ін.) та китайських (Ван Тяньці, Ван Цзяньшу, Лі Лань, Цяо Лінь, Шень Цзіньге та ін.) науковців [7; 16; 17; 18; 19]. Невирішеним виявилося питання щодо обгрунтування педагогічних умов формування готовності майбутніх учителів музики до художньо-інтерпретаційної діяльності. 
Mema cmammi - визначити педагогічні умови формування готовності майбутніх учителів музики до художньо-інтерпретаційної діяльності.

Вивчення наукових праць дозволило проаналізувати різноаспектні тлумачення поняття «педагогічні умови» і на цій основі виділити такі, які найбільше відповідають темі дослідження. На наш погляд, формування готовності студентів до художньоінтерпретаційної діяльності буде успішним за умови: освоєння студентами біофізичних і орфоепічних основ вокальної мови; уважного ставлення до словесного тексту вокального твору, його художньо-образного змісту; розуміння студентами вокальновиконавської стилістики музичного твору. Розглянемо кожну з цих умов окремо.

Необхідність обрання педагогічної умови - освоєння студентами біофізичних і орфоепічних основ вокальної мови - підкріплюється думками багатьох відомих педагогів стосовно вивчення дисципліни «Постановка голосу». За їх переконанням, вона має включати: відомості про анатомо-фізіологічну структуру голосового апарату, профілактику його захворювань, співацьке дихання, типи звучання й класифікації голосів згідно з регістрами та діапазонами, утворюючи теоретичну базу, на яку накладаються подальші знання основ художнього співу й техніки вокально-сценічної творчості (В. Антонюк); грунтуватися на широкому колі знань про природу та механізми звукоутворення, закономірностях формування співацького голосу та керування цим процесом, розумінні сутності складних фонаційних явищ, які відбуваються в людському організмі, забезпечуючи досягнення кінцевого результату - створення художньомузичного образу (Ю. Юцевич); глибокому усвідомлену біофізичних основ співацького голосу, механізмів процесу голосового утворення, володіння грунтовними знаннями 3 питань вокальної педагогіки і таких наук як акустика, біофізика, психологія, фізіологія, орфоепія, фонопедія, гігієна тощо (І. Герсамія); передбачати вивчення організму людини як цілісної системи, в якій слуховий і внутрішній контроль розглядається як основа фонації; внутрішні відчуття як енергетичний (природний) посил; дихання співаків як джерело виразності (В. Юшманов).

Крім того, в основу даної умови покладено положення гуманістичної психології (К. Роджерс, А. Маслоу та ін.), згідно якої основою розвитку вважається природа, котру має при народженні кожна особистість - «...інстинктивні основні потреби, здібності, таланти, анатомія, фізіологічна рівновага або врівноваженість темпераменту. Це 
виявляється у формі природних пристрастей або внутрішніх переконань» [2, с. 56]. Отже, такі біофізичні та психологічні потенційні можливості необхідно враховувати в процесі вокального розвитку. В цьому контексті важливим є твердження К. Ясперса, що без знань про багатство людської природи неможливо зрозуміти й розкрити свій потенціал, стати суб'єктом перетворення світу і самого себе [3, с. 136]. Принцип пізнання біофізичної природи людини націлює суб’єкта навчання на розкриття не тільки своїх вокальних можливостей, а й ціннісно-смислових спрямувань життєдіяльності, які допомагають йому відновлювати гармонію із самим собою.

Дослідження в галузі фізіології й акустики голосового апарату (роботи Л. Дмітрієва, Н. Жинкина, В. Морозова, 3. Ржевкина, Е. Рудакова і зарубіжних учених Ван-ден-Берга, О. Рассела, Г. Портмена та Р. Юссона) спрямовують увагу на особливості формування співацького голосу, а в окремих випадках абсолютно по-новому пояснюють співацьке звукоутворення та орфоепію співочого мовлення. Зазначені дослідники звертаються до питань, пов'язаних 3 орфоепією співочого мовлення, зокрема: яким чином дотримання або ігнорування вимовних норм впливає на якість співаного тексту, чи можливо у співочому мовленні послуговуватись орфоепічними нормами повсякденного мовлення і якими ознаками може відрізнятися співоча орфоепія від мовної.

Вчені дійшли висновку, що дотримання орфоепічної норми є обов'язковим не тільки для всіх носіїв мови, а й для тих, хто хоче ії опанувати. Відхилення від літературної вимови відволікають слухача від змісту сказаного і спрямовують його увагу на звукову форму повідомлення. 3 цього приводу Н. Тоцька наголошує: «...нормативна (усталена, стандартна) вимова забезпечує легкість - отже, й швидкість сприймання змісту звукової мови, тобто полегшує й прискорює процес спілкування. Чітка, виразна, звучна вимова, багата, барвиста інтонація фрази уточнюють вираження думки, посилюють емоційний вплив на слухача» [13, с. 143-144 ].

Аналіз наукових праць 3 даної проблематики засвідчив, що співоча орфоепія відрізняється від мовленнєвої тим, що у вокальній дикції слова ритмічно організовані, і для того, щоб їх проспівати, необхідно зафіксувати та утримувати диханням голосні звуки, завдяки чому виникає спів. У роботах В. Садовнікова «Орфоепія у співі» та А. Реформатського «Мова і музика у співі» наголошується на важливості роботи язика у 
цьому процесі. Вчені пропонують під час співу «утримувати кінчик язика біля нижніх різців, щоби він рухався разом із нижньою щелепою, а також фіксувати і не змінювати положення гортані для всіх голосних. Це позначається на якості звучання голосних звуків у співі: вони змінюють свої основні характеристики, наближаючись один до одного. У системі приголосних відхилень від норми має бути значно менше, оскільки артикулювати їх потрібно так, як у звичайному мовленні» $[9 ; 10 ; 6]$.

Проте у ході спостережень за вимовою приголосних звуків у співі, дослідники виявили, що зосередження уваги на артикуляції голосних звуків стає причиною недостатньої уваги до приголосних, про що свідчать численні відхилення від норми у співочому мовленні: вимова звичайних приголосних на місці подовжених, пом'якшення шиплячих, артикуляція шиплячих звуків замість твердих тощо.

3 цього приводу П. Турянський відзначає, що, перш за все, потрібно «добиватися ясної чіткої дикції, при відсутності якої найталановитіші твори не досягають художнього відтворення. При вимовлянні приголосних має бути відчуття міри, тобто необхідно обережно підходити до потрібного їх подвоєння» [14, с. 103-105].

Цікавою є думка А. Ковбасюка, висловлена в статті «Фонетика мови та її вплив на спів»: «вокальна фонетика української мови, ії закони дещо відрізняються від вокальної фонетики російської мови. Одна з особливостей полягає в тому, що у співі українською мовою не змінюються голосні, тобто характер їхнього звучання, акустичні характеристики майже не залежать від позиції у слові. Вони вимовляються тим самим укладом мовних органів, що й наголошені голосні. Ця риса збільшує «вокальність» української мови» [4, c. 117].

Таким чином, підсумовуючи огляд наукових праць констатуємо: культура мови у співі грунтується на законах орфоепії, які зумовлені фонетичною природою певної мови; вокальний твір, написаний у фонетичній системі конкретної мови, містить в собі іiі елементи (фонеми, інтонації та закони, за якими ця система функціонує); орфоепічна норма у співочому мовленні зазнає певних порушень, які в одних випадках полегшують процес співу для виконавців, а з іншого боку, часто впливають на погіршення його дикції, зниження мелодійності співочого мовлення, погіршення загального враження слухачів від почутого музичного твору; проте специфіка вокальної мови, залежність їі від вокально-музичних умов (висоти, темпу, регістру тощо) породжують ряд фонетичних 
закономірностей, які не дозволяють автоматично переносити орфоепічні закони сценічної мови у спів.

На переконання В. Чернишук, усі відмінності від мовленнєвої норми у співі можна поділити на ті, які виправдовуються вокальною технікою, i ті, що спричинені недотриманням орфоепічної норми окремим співаком. До першої групи, насамперед, відносимо випадки якісної редукції голосних звуків, порушення акцентуаційної норми, до другої - неправильну вимову приголосних звуків: пом'якшення шиплячих, оглушення дзвінких, відсутність вокалізації сонорних тощо [15]. Проте, у будь-якому випадку необхідно дотримуватись думки відомого українського співака і педагога О. Мишуги: «Спів є також мова, але тільки з подовженими складами та у відповідних музичновокальних звуках... для того, щоб добре співати, необхідно навчитися правильно і виразно говорити».

У відповідності зі сказаним вважаємо, що формування готовності студентів до художньо-інтерпретаційної діяльності буде успішним за умови уважного ставлення до словесного тексту вокального твору, його художньо-образного змісту. На важливості слова у співі наголошували педагоги та виконавці різних епох. Великого значення слову надавали такі відомі співаки як Е. Карузо, Ф. Шаляпін, С. Крушельницька, О. Мишуга, Є. Мірошниченко, В. Степова та ін. Відзначимо, що у різних історичних та національних вокальних школах підхід до словесного тексту був досить різним. Так, в італійській музиці, у добу bel canto, слово посідало другорядне значення, головна увага зверталася на віртуозне володіння голосом, а словесний текст повністю підпорядковувався нотам. У виконанні італійцями найбільше цінувалась технічна досконалість, зовнішні голосові ефекти, вміння орнаментувати мелодію вишуканими каденціями.

Українська та російська вокальні школи, навпаки, спрямовувались на взаємозв'язок слова і музики, а технічна віртуозність ніколи не була кінцевою метою вокального навчання. Вимагаючи від учнів володіння синтезом слова i співу, викладачі наголошували, що «слово потрібно любити не менше, ніж свій власний голос і так само наполегливо працювати над ним» [15]. Успішність виконання вокального твору залежить від якості словесного тексту, а також від здатності вокаліста відчувати поетичність слів, які він співає. Перетворюючи свій спів на живе музичне мовлення, виконавець має можливість розкрити музично-поетичний образ, який є відображенням 
авторського задуму музичного твору, представленого крізь призму його індивідуальності, суб'єктивного бачення і відчуття музичної дійсності. Для досягнення вершин вокальної майстерності кожному співаку необхідно прагнути до художньоправдивих інтонацій вокального слова, що досягається засобом уважного і глибокого вивчення історії, традицій, особливостей фонетики та граматики мови. Особливо показовим у цьому сенсі є український фольклор, де в самому слові зконцентровано головне образно-емоційне навантаження. Вчені відзначають, що українська народна пісня не сприймає душевної фальші. Зокрема П. Турянський пише: «Слово, вимовлене в пісні невиразно і формально, погубить іï; і ми часом бачимо, що пісня не удалася співакам навіть з хорошими голосовими даними, оскільки їм не вистачає задушевності й художньої правди» [14, с. 34].

Враховуючи важливе значення поетичного тексту для інтерпретації вокального твору, В. Васіна-Гроссман запропонувала метод вивчення вокального твору, який грунтується на виявленні загальних властивостей поезії та музики, що сприяють органічному їх поєднанню в різних вокальних формах. До них належать ритміка, інтонація і композиція. Автор підкреслює, що у процесі написання вокального твору літературне першоджерело багато в чому визначає зміст музичного тексту. Процес створення вокального твору безпосередньо пов'язаний з ритмічними особливостями поетичного тексту та своєрідним в кожну історичну епоху способом сприйняття й інтонування вірша.

У роботі «Музика і поетичне слово» В. Васіна-Гроссман чітко розмежовує поетичний метр (як узагальненої схеми чергування наголошених і ненаголошених складів) і поетичний ритм (як індивідуальне, реальне заповнення цієї схеми), що дає можливість розкрити індивідуальність сприйняття композитором поетичного слова. Дотримуючись логіки розвитку поетичного слова, музика також рухається від переважаючого віддзеркалення метрики до відтворення ритму вірша, тобто шляхом деталізації кожного окремого поетичного сегмента. Вчена звертає увагу на те, що в поетичному творі «запрограмоване» не одне, а багато музичних рішень, зокрема й композиційних [2]. Таким чином, музичне втілення поетичного тексту, його інтерпретація залежить від талановитості композитора і виконавця. 
Формування готовності до художньо-інтерпретаційної діяльності буде успішним за умови розуміння студентами вокально-виконавської стилістики музичного твору. Така стилістика досліджує еволюцію музичних стилів у відповідності з історією розвитку музичного мистецтва, мову музичних творів, експресивні засоби музичної мови, інтонаційний склад та композиційну побудову. Крім цього, вона спрямована на вивчення стилю в усіх значеннях цього терміну (індивідуальна манера виконання, стиль вокального мовлення, стиль музичного висловлювання тощо).

У вокальному мистецтві розуміння стилістики пов'язане 3 фіксацією і відображенням особливостей співу певної епохи. Ці особливості впливають на композиторську творчість і визначають характер вокального інтонування музичного твору, теситуру співу й вокальний діапазон, формування типу голосу людини [11, с. 17]. У посібнику О.Стахевич «3 історії вокально-виконавських стилів та вокальної педагогіки» наголошується, що вокальна стилістика оперних та хорових творів формувалася завдяки взаємодії композиторської творчості, вокальної педагогіки і вокально-виконавської практики, тобто їхньому синтезу. «Еволюція мистецтва співу, наголошує вчена - це еволюція вокально-виконавських стилів, кожен з яких грунтується на власній теорії, яка може не відповідати і навіть заперечувати стиль передньої та наступної епох... . Вивчення цієї проблеми в історичному аспекті пояснює характер звучання співацького голосу і стилістику вокального інтонування музичних творів різних епох» [9, с. 7]. Розглядаючи стилістичні особливості класичного bel canto, автор розкриває характер вокального інтонування, діапазон та теситуру голосів, принципи та їх еволюцію, що призвела до виховання природніх жіночих і чоловічих голосів, виявлення їх співацьких можливостей, і взагалі, до корінних перетворень у методиці навчання співу. Автор наголошує, що стиль класичного bel canto значно відрізняється від сучасного стилю сольного співу як за технічними, так і художніми параметрами. Стилістика ж народного співу, на думку О.Стахевич, як правило, визначається використанням грудного регістру відкритого звучання і у чоловіків, і у жінок [11, с. 7].

Важливі питання вокальної оперної стилістики висвітлюються в дисертаційному дослідженні А. Помпеєвої. Посилаючись на положення А. Сохора, що стиль в опері $\epsilon$ ключем до діалогу між культурними епохами, автор простежує еволюцію вокальної стилістики в опері від епохи бароко, коли сформувався «театральний стиль» до 
експресіонізму та постмодернізму», вона аналізує як загальні тенденції, так і конкретні стильові прояви зазначеного явища. Автор відзначає, що вокальна стилістика опери знаменувала значні зрушення у природі музичного мислення, поступово виводячи на перший план соліста-віртуоза та арію як носія нової вокально-концертної форми (стилістика бельканто). Вчена стверджує, якщо у класичному італійському bel canto середини XVII - першої половини XIX століть головною стилістичною вимогою була кантилена, співучість виконання, то з середини XIX століття вокальна стилістика базувалась переважно на жанрах національно-фольклорного походження 3 підкресленням у вокальній мові «естетики крику». На прикладі опери-новели П. Масканьї «Сільська честь» А. Помпєєва демонструє метаморфози вокальної стилістики. Вона вважає, що ця опера є центром тяжіння, від якого походять різні стилістичні перетворення, адже їі драматургія поєднує риси «опери, що співається» (3 акцентом на сольно-вокальній складовій як смисловому ядрі драми) та симфонізованої опери-драми, де діє іманентно музична логіка. У підсумку автор констатує, що сучасна опера вирізняється стилістичним плюралізмом, оскільки під впливом музики, театру і літературного тексту формується «третя реальність» (Б. Брехт) - відчуття своєрідного симбіозу цих складових під егідою інтонаційно-музичного начала [8, с. 4-7]. На наш погляд, ознайомлення студентів з оперною стилістикою стане основою для формування готовності до художньо-інтерпретаційної діяльності.

Великого значення у процесі інтерпретації вокальних творів набуває сюжетна стилістика, яка у вокальній музиці набуває вираження розповіді в особах, або театру одного актора. Свої прийоми сюжетна стилістика запозичує з літератури (розповідіречитативи, що підкреслюються тембровою персоніфікацію музичних образів), поезії (емоційні напливи, ремінісценції), драматургії (вторгнення, діалоги персонажів тощо). В цьому контексті доцільно процитувати думку Ю. Борєва: «музикант інтерпретує твір, який виконує. літературний критик - твір літератури, перекладач - думки, виражені на мові оригіналу, мистецтвознавець - картину, математик - формулу» [1, с. 426]. Що стосується музиканта-вокаліста, мова йде про надання онтологічного буття «потенційній музиці», яка зашифрована в нотах, а підсумком такого розшифрування стає створення переконливої інтерпретації художнього образу.

Отже, саме в процесі виконавської інтерпретації (аналізу самостійної, репетиційної 
та концертної стадій) складається уявлення про індивідуальний виконавський стиль вокаліста.

Вивчення індивідуального виконавського стилю здійснюється за декількома напрямками. Одним з них є вивчення об'єкту інтерпретації, тобто - який твір і як інтерпретує його даний виконавець. Важливим напрямом вивчення індивідуального виконавського стилю є аналіз творів 3 репертуару вокаліста. Зокрема його жанрова систематизація, встановлення пріоритетних для даного виконавця історичних, національних та авторських стилів. Також визначальним для дослідженням індивідуального виконавського стилю є порівняльний аналіз здійснених виконавських версій музичних творів - тобто результату інтерпретації. Враховуючи сказане, індивідуальний виконавський стиль вокаліста будемо розглядати як комплекс виконавських (загальних, спеціальних, технічних) прийомів і засобів, що визначається специфікою вокального виконавства, складовими творчого методу вокаліста, особливостями виконуваного твору, що реалізується в процесі виконавської інтерпретації [10, c. 440].

3 огляду на існуючу типізацію виконавських стилів, враховуючи унікальність виконавського стилю кожного вокаліста, дослідники (Ю. Ткач, В.Живов та ін.) наголошують на трьох основних типах виконавських стилів - раціоналістичному, емоційному та синтетичному. Раціоналістичний тип характеризується об'єктивізмом, точним розрахунком інтерпретації, логікою виконавського задуму, вмінням споруджувати 3 деталей монолітні конструкції. Для емоційного типу властиве домінування емоційного початку, артистична свобода, яка заснована на суб'єктивному відчутті, інтуїциї, імпульсивності, стихійності. Синтетичний тип характеризується глибиною, проникливістю виконання, емоційністю без стихійності, аргументованим, логічним суб'єктивізмом, продуманою імпровізацією тощо [10, с. 440]. Знання цієї типології дозволить майбутньому вчителю виважено ставитись до вивчення та виконання вокальних творів різних стилів і жанрів. При вивченні вокального твору також необхідно враховувати взаємозв'язок музичних стилів із стильовими особливостями інших видів мистецтв (живопису, літератури). Відчуття таких зв'язків, на наш погляд, сприятиме успішності художньо-інтерпретаційної діяльності вчителя музичного мистецтва. 
Висновки. Підсумовуючи сказане відзначимо, що розглянуті педагогічні умови у практиці вокальної підготовки китайських студентів сприятимуть залученню до художньо-інтерпретаційної діяльності як дієвої форми виявлення їх творчого потенціалу. Своєю чергою, реалізація означених умов повинна відбуватися як в процесі навчальних занять, так і в період педагогічної практики, при підготовці до концертних виступів, де безпосередньо відбувається процес художньо-інтерпретаційної діяльності. Подальшого розроблення потребує теоретичне та методичне забезпечення процесу формування готовності майбутнього вчителя музики до художньо-інтерпретаційної діяльності.

\section{References}

1. Borev Y.U. Éstetyka: Otnoshenye $k$ deystvytelnosty; Tvorchestvo; Khudozhestvennyy protsess; Obrashchenye s yskusstvom [Aesthetics: Relation to reality. Creation; Artistic process. The treatment of art]. 2005. 623 p.

2. Vasyna-Hrossman V.A. Muzyka y poetycheskoe slovo [Music and a poetic word] : in 3 parts. Part 1. 1972. 149 p., Parts 2-3. 1978. 365 p.

3. Vakhromov E.E. Psykholohycheskye kontseptsyy razvytyya cheloveka: teoryya samoaktualyzatsyy [Psychological concepts of human development: the theory of selfactualization]. 2001. $162 \mathrm{p}$.

4. Kovbasyuk A. V. Fonetyka movy ta yiyi vplyv na spiv [Phonetic language and its influence on singing]. Visnyk Lvivskoho universytetu: Seriya mystetstvo. 2012. No. 11. P. $117-$ 122.

5. Mozhalova N.H. Teoretyko-metodychni zasady instrumental'no-vykonavs'koyi pidhotovky vchytelya muzyky [Theoretical-methodical ambush of instrumental-wikonavs'ko podgotovki listener of music]. 2012. $488 \mathrm{p}$.

6. Pet'ko L.V. Robota nad pisneju v kursi anglijs'koi' movy jak odyn iz zasobiv profesijnoi' pidgotovky studentiv gumanitarnyh special'nostej VNZ [The song in English course as a means of training humanities majors university students']. Inozemni movy. 2011. No. 1 P. 44-48.

7. Pet'ko L.V. Shljahy formuvannja inshomovnoi' sociokul'turnoi' kompetencii' studentiv mystec'kyh special'nostej VNZ u procesi fahovoi' pidgotovky [The Ways of Formation of Foreign Language Socio-Cultural Competence of Students of Music-Pedagogical Specialties in Higher School in the Process of Professional Teaching]/ Problemy pidgotovky suchasnogo vchytelja: zb. nauk. pr. Umans'kogo derzhavnogo ped. un-tu imeni Pavla Tychyny. Uman' : PP Zhovtyj O.O., 2012. Vol. 6. Part 3. P. 57-62.

8. Pompyeyeva A.YU. Vokal'na stylistyka u yevropeys'kiy operi maloyi formy kintsya $X I X-X X$ stolit [Vocal stylistics in the European opera of the late 19th-20th centuries: author's abstract. sciences step cand. Arts]: avtoref. .. nauk. stup. kand. mystetst. 2017. 20 p. 
9. Reformatskyy A.A. Rech y muzyka v penyy [Speech and music in singing]. Voprosy kultury rechy. 1955. P. 172-207.

10. Sadovnykov V.V. Orfoépyya v penyy [Orthoepy in singing].1958. 156 p.

11. Stakhevych O.H. Z istoriyi vokalno-vykonavskykh styliv ta vokalnoyi pedahohiky [From the history of vocal-wikonavskikh style and vocal pedagogy]: posibnyk. 2013. 176 p.

12. Tkach YU.K. Spetsyfika dyryhent $\cdot$ 'koyi interpretatsiyi u khorovomu vykonavstvi [The specifics of interviews and choirs in the choir conquest]. Problemy muzychnoho mystetstva XX storichchya. 2014. P. 440-448.

13. Totska N.I. Suchasna ukrayins'ka literaturna mova: fonetyka, orfoepiya, hrafika, orfohrafiya [Modern Ukrainian literary language: phonetics, spelling, graphing, spelling]. 1981. P. 143-144.

14. Turyanskyy P.K. Slovo - osnova vyraznosti u vokal'nomu vykonavstvi [The word is the basis of the difference in vocal perception.]. Molod i rynok. 2012. No. 1(84), C. 103-105.

15. Chernyshuk V.V. Spivoche movlennya $i$ orfoepichna norma [Singing language and ordinal norm]. Profesionalizm pedahoha: teoretychni y metodychni aspekty. 2010. Vol. 6. P. 347-353.

16. Komarovska Oksana, Huang Hanjie. Readiness for stage partnership in vocalensemble performance as a vector in professional training music teacher. Intellectual Archive. Toronto: Shiny World Corp. (Canada). 2018. (September/October). Vol. 7. No. 5. PP. 66-74. https://doi.org/10.32370/2018_09_7

17. Pet'ko Lyudmila. The development of student youth aesthetic culture on professional direction // Topical issues of contemporary science: Collection of scientific articles. - C.E.I.M., Valencia, Venezuela, 2017. P. 188-192.

18. Shcholokova O.P. Art and pedagogical designing as a means of improvement of music teacher's professional preparing // Economics, management, law: socio-economical aspects of development: Collection of scientific articles. Vol. 2. Edizioni Magi. Roma, Italy. 2016. P. 265-268.

19. Chen Kai, Shcholokova Olga. Methodological basis of the future musicianseducators' performance-educational activity. Intellectual Archive. - Toronto: Shiny World Corp. (Canada). 2018. (May/June). Vol. 7. No. 3. PP. 94-104.

Translation of the Title, Abstract and References to the Author's Language УДК: 378.016: [784:781.68] (043.3)

Лінь Янь. Педагогічні умови формування готовності майбутніх учителів музики до художньо-інтерпретаційної діяльності.

В статті обгрунтовано педагогічні умови формування готовності майбутніх учителів музики до художньо-інтерпретаційної діяльності, а саме: освоєння студентами біофізичних і орфоепічних основ вокальної мови; уважного ставлення до словесного тексту вокального твору, його художньо-образного змісту; розуміння студентами вокально-виконавської стилістики музичного твору. Відповідно до першої умови, даний процес повинен грунтуватися на широкому колі знань про природу та механізми 
звукоутворення, закономірностях формування співацького голосу та керування цим процесом, розумінні сутності складних фонаційних явищ, які відбуваються в людському організмі, забезпечуючи досягнення кінцевого результату - створення художньопереконливої інтерпретації вокального твору. Дотримання другої умови пов'язано 3 уважним ставленням до словесного тексту вокального твору, його художньо-образним змістом. Виконання третьої умови передбачає ознайомлення студентів 3 еволюцією музичних стилів у відповідності 3 історією розвитку музичного мистецтва, експресивними засобами музичної мови, іiі інтонаційним складом та композиційною побудовою. Реалізація означених умов повинна відбуватися як в процесі навчальних занять, так і в період педагогічної практики, при підготовці до концертних виступів, де безпосередньо відбувається процес художньо-інтерпретаційної діяльності.

Ключові слова: студенти, готовність, вокальний твір, інтерпретація, художньоінтерпретаційна діяльність, орфоепія, стилістика.

\section{Jimepamypa}

1. Борев Ю. Эстетика: Отношение к действительности; Творчество; Художественный процесс; Обращение с искусством. 2005. 623 с.

2. Васина-Гроссман В. А. Музыка и поэтическое слово : в 3 ч. Ч. 1. 149 с. Ч. 2-3. $365 \mathrm{c}$.

3. Вахромов Е.Е. Психологические концепции развития человека: теория самоактуализации. 2001. 162 с.

4. Ковбасюк А.В. Фонетика мови та іï вплив на спів. Вісник Львівського університету : Серія мистецттво. 2012. № 11. С. 117-122.

5. Мозгальова Н.Г. Теоретико-методичні засади інструментально-виконавської підготовки вчителя музики. 2012. 488 с.

6. Петько Л.В. Робота над піснею в курсі англійської мови як один із засобів професійної підготовки студентів гуманітарних спеціальностей ВНЗ Іноземні мови. 2011. № 1 С. $44-48$.

7. Петько Л.В. Шляхи формування іншомовної соціокультурної компетенції студентів мистецьких спеціальностей ВНЗ у процесі фахової підготовки. Проблеми підготовки сучасного вчителя : зб. наук. праць Уманського державного педагогічного університету імені Павла Тичини / [ред. кол. : Побірченко Н. С. (гол. ред.) та ін.]. - Умань : ПП Жовтий О. О., 2012. Вип. 6. Ч. 3. С. 57-62.

8. Помпєєва А.Ю. Вокальна стилістика у європейській опері малої форми кінця XIX - XX століть: автореф. наук. ступ. канд. мистецт. 2017. 20 с.

9. Реформатский А.А. Речь и музыка в пении. Bonpocы культуры речи. 1955. № 1. C. 172-207.

10. Садовников В. В. Орфоэпия в пении.1958. 156 с.

11. Стахевич О.Г. 3 історії вокально-виконавських стилів та вокальної педагогіки: посібник. 2013. 176 с.

12. Ткач Ю.К. Специфіка диригентської інтерпретації у хоровому виконавстві. Проблеми музичного мистецтва ХХ сторіччя. 2014. С. 440-448. 
13. Тоцька Н.І. Сучасна українська літературна мова: фонетика, орфоепія, графіка, орфографія. 1981. С. 143-144 .

14. Турянський П.К. Слово - основа виразності у вокальному виконавстві. Молодь і ринок. 2012. № 1 (84). С. 103-105.

15. Чернишук В. В. Співоче мовлення і орфоепічна норма. Професіоналізм педагога: теоретичні й методичні аспекти. 2010. №6. С. 347-353.

16. Komarovska Oksana, Huang Hanjie. Readiness for stage partnership in vocal-ensemble performance as a vector in professional training music teacher. Intellectual Archive. - Toronto: Shiny World Corp. (Canada). 2018. (September/October). Vol. 7. No. 5. PP. 66-74. URL: https://doi.org/10.32370/2018_09_7

17. Pet'ko Lyudmila. The development of student youth aesthetic culture on professional direction // Topical issues of contemporary science: Collection of scientific articles. - C.E.I.M., Valencia, Venezuela, 2017. P. 188-192.

18. Shcholokova O.P. Art and pedagogical designing as a means of improvement of music teacher's professional preparing // Economics, management, law: socio-economical aspects of development: Collection of scientific articles. Volum 2. Edizioni Magi. Roma, Italy. 2016. P. 265-268.

19. Chen Kai, Shcholokova Olga. Methodological basis of the future musicianseducators performance-educational activity. Intellectual Archive. - Toronto: Shiny World Corp. (Canada). 2018. (May/June). Vol. 7. No. 3. PP. 94-104. 